\title{
Albertyn lewer 'n onskatbare bydrae tot die Afrikaanse drama
}

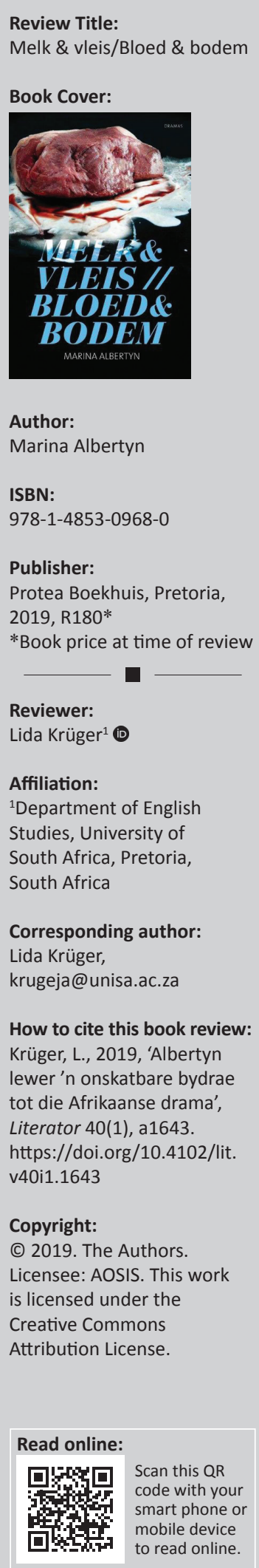

Marina Albertyn se Melk $\mathcal{E}$ vleis/Bloed $\mathcal{E}$ bodem word op die omslag beskryf as 'Twee plaasdramas oor grense, tradisie, grond en bloed'. Hierdie beskrywing roep reeds verskeie Afrikaanse dramas op, soos Reza de Wet se Diepe grond (1985), Deon Opperman se Kaburu (2007) en Saartjie Botha se Saad (2008). Hierdie temas is so bekend in die Afrikaanse drama dat dit moeilik is om daaroor te skryf sonder om in clichés te verval. Albertyn kry dit egter reg om hierdie uitdaging op ' $n$ besonder gesofistikeerde manier te oorkom.

Melk $\mathcal{E}$ vleis is 'n transponering van Euripides se Medea (431 v.C.) na 'n plaas in postapartheid Suid-Afrika. Medea was 'n suksesvolle aktuaris wat in die stad gewoon het, totdat sy verlief geraak het op Johannes en haar geld en besigheidsvernuf gebruik het om sy familieplaas van bankrotskap te red. Die paartjie lyk aanvanklik gelukkig, maar hulle verhouding rafel stelselmatig uit soos die drama voortgaan. Die teks het dieselfde onheilspellende ondertoon as De Wet se Diepe grond, met die huishulp, Bongi, en haar dogter, Esona, wat 'n soortgelyke magiese atmosfeer aan die stuk verleen as ou Alina in Diepe grond. Ook die wreedheid in Melk $\mathcal{E}$ vleis herinner aan De Wet se teks en daarom sou dit beskou kon word as 'n terugskrywe aan Diepe grond vanuit 'n postapartheid konteks.

In Bloed $\mathcal{E}$ bodem is Jana 'n student aan die Universiteit van die Vrystaat se landbouskool. Sy is bekommerd dat haar pa se depressie en alkoholisme hul familieplaas laat agteruitgaan en kom kuier onverwags. Met die aansporing van haar oom, Johan, besluit Jana om haar studie opsy te skuif en heeltyds te boer. Dit lyk egter asof Johan se verknogtheid aan haar ontstellende afmetings aanneem.

Marina Albertyn se dramas staan kop en skouers uit bo enige nuutgeskrewe werk wat ek die afgelope dekade op Afrikaanse verhoë gesien het. Die bekende ruimtes van onderskeidelik 'n plaaskombuis of woonvertrek word die terrein van 'n wrede afloop wat onafwendbaar binne die patriargale konteks van die dramas blyk te wees. Hoewel hierdie eerlike blik op die Afrikaanse kultuur op sigself vir boeiende toneeltekste sou sorg, beïndruk Albertyn ook op tegniese vlak. Sy kry dit reg om 'n verbasende hoeveelheid inligting op 'n besonder ekonomiese manier oor te dra, wat sorg vir 'n ongeforseerde eksposisie. In Melk $\mathcal{E}$ vleis, byvoorbeeld, besef die leser binne die bestek van drie bladsye dat Medea en Johannes verskillende sienings het oor kinders, die politiek en geloof, dat daar spanning is tussen Medea en haar skoonfamilie, dat sy sukkel om by die plaasgemeenskap in te pas en dat dit, ten spyte hiervan, aanvanklik goed gaan met Medea en Johannes se verhouding.

Albertyn is ook besonder vaardig met die voorafskaduwing van gebeure. In Bloed E bodem is daar van die begin af 'n dreigende atmosfeer wat geskep word deur die karakters se bemoeienis met veiligheid, en veral gevare van buite. Soos dikwels die geval is in 'n patriargale gemeenskap, kom die gevaar egter eerder van binne. Dit word uitstekend deur Johan vooruitgeskou wat knaend vir Jana soengroet, haar telkens komplimenteer, en deur sy woordkeuse wanneer hy sy gehegtheid aan haar verduidelik: ' $[E] \mathrm{k}$ is al verlief op jou van jy die eerste keer vir ons met jou skopfiets kom kuier het.' Wanneer al hierdie dinge apart beskou word, kan dit as onbelangrik afgemaak word, maar saam word dit 'n onomwonde aanduiding van die steurende gebeure wat volg.

Daar is wel 'n paar spel- en ander foute in die teks wat met deegliker proeflesing uitgeskakel kon word. Ek vind dit ook jammer dat daar nie 'n Afrikaanse vertaling ingesluit word vir Bongi se isiXhosa monoloog waarmee Melk $\mathcal{E}$ vleis begin nie, veral omdat Bongi en Esona as 'n Griekse koor funksioneer.

Ek het albei hierdie stukke tydens hulle eerste opvoerings gesien. Die dramas is toneelmatig en sorg vir 'n ryk teaterervaring, maar met die lees van die tekste kan hulle kompleksiteit verder ontgin word. Die teks is dus geskik vir diegene wat die opvoerings gewaardeer het en verder 
daarin wil delf. Die verwikkeldheid van die dramas noop navorsers en studente ook om die gepubliseerde teks te bestudeer.

Albei hierdie dramas beeld karakters uit wat by die sosiale veranderings om hulle probeer aanpas. Sommige is hardkoppig en rassisties en ander probeer progressief wees, maar hulle onbeholpe pogings tot versoening blyk selfdienend te wees. Die stukke ontmasker konsepte soos plaas, grond en boer as mites, sonder om die krag van mites te onderskat. Dit is dus 'n ongemaklik eerlike blik op wit, Afrikaanssprekende Suid-Afrikaners en hul verhouding tot die patriargie, grondbesit en die moontlikheid van 'n nie-rassige samelewing.

Albertyn se tekste is ' $\mathrm{n}$ groot aanwins vir die Afrikaanse dramaskat. Die publikasie daarvan maak dit vir verdere bespreking en opvoering beskikbaar. 